Parting Ways 
This page intentionally left blank 


\section{Parting Ways}

N E W R I T UALS A N D

C E L E B R A T I O N S O F

L I F E' S P A S I N G

D E N I S E C A R S O N

뚜

U N I VER S T Y OF CA L I FOR N A PR E S

Berkeley Los Angeles London 
University of California Press, one of the most distinguished university presses in the United States, enriches lives around the world by advancing scholarship in the humanities, social sciences, and natural sciences. Its activities are supported by the UC Press Foundation and by philanthropic contributions from individuals and institutions. For more information, visit www.ucpress.edu.

University of California Press

Berkeley and Los Angeles, California

University of California Press, Ltd.

London, England

(c) 2011 by The Regents of the University of California

Library of Congress Cataloging-in-Publication Data

Carson, Denise.

Parting ways : new rituals and celebrations of life's passing /

Denise Carson.

p. $\mathrm{cm}$.

Includes bibliographical references.

ISBN 978-0-520-25108-3 (cloth)

ISBN 978-0-520-26873-9 (pbk.)

1. Death-Psychological aspects. 2. Mourning customs.

3. Funeral rites and ceremonies. I. Title.

BF789.D4C32 2011 155.9'37—dc22 2010040360

Manufactured in the United States of America

$\begin{array}{llllllllll}20 & 19 & 18 & 17 & 16 & 15 & 14 & 13 & 12 & 11\end{array}$

$\begin{array}{llllllllll}10 & 9 & 8 & 7 & 6 & 5 & 4 & 3 & 2 & 1\end{array}$

The paper used in this publication meets the minimum requirements of ANSI/NISO Z39.48-1992 (R 1997) (Permanence of Paper). 
To my parents, Linda and Richard Carson

Your love and spirit of adventure live on 
This page intentionally left blank 